\section{Basis of costings}

Oto-admittance cannot be regarded as an expensive medical technique. Stoney and Rogers emphasise the high initial cost of some types of oto-admittance equipment, but some cost as little as $£ 1300$. In health-economic terms, the initial capital purchase cost of one item of equipment is not a very relevant measure of cost. If the allocation system still makes initial cost the only hurdle, or an insuperable hurdle, then the system is bad. More relevant, one $£ 3000$ oto-admittance meter lasting 10 years, plus calibration, stationery and occasional repairs will cost about $£ 1$ per calendar day. The salary bill plus staff overheads for ENT an out-patient department plus audiology in a medium-sized health district is about $f 1000$ per calendar day. Parsimony would be better focussed elsewhere.

Yours faithfully,

M. P. Haggard and M. E. Lutman

MRC Institute of Hearing Research

Nottingham NG7 2RD.

\section{References}

Brostoff, L. M., Cantekin, E. I. (1988) Observer-invariant diagnosis of middle ear effusions. In Lim, D. J. (Ed) Advances in Otitis Media, p. 47-49. Philadelphia: Decker.

Stoney, E., Rogers, J. (1989) Attitudes to tympanometry. Journal of Laryngology and Otology, 103: 657-658.

Tos, M., Stangerup, S.-E., Hvid, G., Andreassen, U. K. (1988) Epidemiology and natural history of secretory otitis. In Lim, D J. (Ed) Advances in Otitis Media, 29-34. Philadelphia: Decker.

Dear Sir,

We thank M. E. Haggard and M. P. Lutman for their detailed and comprehensive comments on our paper on attitudes to tympanometry.

In the design of the questionnaire we felt that the verbal scale was as valid as any other method for a subjective assessment, and more likely to be answered by the ENT Consultants than an analogue or percentage scale.

We do not agree that the result leads to the conclusion that professional attitudes are arbitrary, and simply feel that there is a wide divergence. We admit the basis for this has not been fully explored in the questionnaire, but we thought more questions would reduce the return rate, which in the event was acceptably high at 75 per cent.

The advantages or otherwise of tympanometry over masked bone conduction were not addressed in the paper, as the difficulties of the latter in young children are well known. We believe that otoscopy, preferably with a pneumatic attachment, can give a great deal more information than tympanometry, and is just as 'standardised' as the diverse tympanometers available. Otoscopy cannot always be performed adequately, but this is also true of tympanometry. There is a danger that too great a reliance on tympanometry by junior ENT Doctors, will result in a deterioration in standards of clinical examination.

Most importantly, we believe that the greatest reliance should be placed on the history, as explained in the paper, and any investigation should be secondary to this. Indeed many investigations are employed as an inadequate substitute for the taking of an accurate history.

As far as the cost is concerned, the comparison with the daily total bill of an ENT and Audiology department is misleading, as this money is already committed and not available for reallocation. What should be debated is the best use of the limited additional funds which are available

Yours faithfully,

P. J. Stoney

Senior Registrar in ENT

University Hospital of

Wales

Cardiff CF4 4XW.

\section{Lipoma and the Liposarcoma: genuine angiogenic lesions}

Dear Sir,

I read with interest the article by Blanshard and Veitch (1989) about the ossifying lipoma. A concomitant proliferation of two mesenchymal phenotypes suggests that this tumor originates in a multipotential undifferentiated mesenchymal cell. The question is that, with some exceptions, such cells do not exist in a normal postnatal organism (Beranek and Friedenstein, 1988) and an alternative hypothesis must be formed.

Recently, we proposed an 'angiogenic hypothesis of repair and fibrosis' (Beranek et al., 1986) according to which proliferating capillary endothelial cells acquire undifferentiated potentialities and are able to give rise to other mesenchymal cell phenotypes. At this occasion, we suggested that in some composite vascular tumours in which the proliferation of two or three distinct cellular populations simultaneously occurs may also originate from such undifferentiated endothelial cells'. We had in mind the haemangioleiomyoma, the haemangiopericytoma, the angiomyolipoma, etc. A separation of angiolipomas as an entity is based on some distinctive features such as a predominance of vessels, infiltrative nature, and frequent recurrence (Hajdu, 1979). In substance, however, all lipomas are of vascular origin. Sarkisov $e t$ al. (1984a) have shown that in normal adipose tissue and lipomas only capillary cells divide, suggesting that adipocytes originate from them.

A phenomenon that only capillary cells contribute to tumoral growth has also been described in the desmoid tumor (Sarkisov et al., 1984b), in.the benign histiocytofibroma, and Dupuytren's fibromatosis (Pierard et al., 1985). Moreover, it has been observed that: 1) pericytes possess Weibel-Palade bodies, a marker of endothelial cells, suggesting that both cell types derive from the same stem cell (Zelickson, 1966) 2) benign mesenchymal nonhaematopoietic tumors often manifest Factor VIII-related antigen, a marker of endothelial cell, in their stromal cells (Morales et al., 1981; Giddens el al., 1985; McWilliam and Harris, 1985; Buley et al., 1988; Hultberg et al., 1988; Smolle et al., 1989), suggesting that these cells derive from undifferentiated vascular endothelial cells, and 3 ) in the same tumors, mitoses in stromal cells are notoriously and extremely rare. On the basis of the above evidence, it may be concluded with a reasonable certainty that mesenchymal benign tumors originate from vasoformative undifferentiated dividing mesenchymal cells and form their stromal cells by a migration of vascular cells into the extravascular space, and their differentiation and maturation there. 
In return, malignant counterparts of the above tumors manifest mitoses in their stromal cells, suggesting that these cells either do not undergo complete maturation or their maturation concerns only some cells. In this way, their angiogenic origin is concealed and only some histopathological features remind us of their origin from vasculogenic mesenchyme. In case of the liposarcoma, they are: 1) an intimate relationship between tumor cells and capillaries (Hajdu, 1979) 2) focal cartilaginous, osseous, and fibroblastic differentiations (cf. Beranek and Friedenstein, 1988) 3) malignant fibrous histiocytoma-like patterns (cf. Sun et al., 1982) 4) haemangiopericytomalike patterns, haemangioma-like patterns, and malignant mesenchymoma-like patterns (Enzinger and Weiss, 1988)

The angiogenic origin of the lipoma and the liposarcoma suggests that therapeutic antiangiogenesis may be tried in their treatment (Beranek, 1988; Beranek, in press).

Yours faithfully,

J. T. Beranek, MD

Research Associate

Division of Cardiothoracic Surgery

Harper Hospital

Department of Surgery

Wayne State University School of Medicine

Detroit, MI 48201 USA.

\section{References}

Beranek, J. T. (1988) Antiangiogenesis comes out of its shell. Cancer Journal, 2: 87-88.

Beranek, J. T. (in press) Transformation of capillaries into interstitial tissue: further evidence in favour of the angiogenic hypothesis of repair and fibrosis. British Journal of Plastic Surgery.

Beranek, J. T., Friedenstein, A. (1988) Letters to the Editor. Cell and Tissue Kinetics, 21: 375-277.

Beranek, J. T., Masseyeff, R., Desmet, V. J. (1986) Hyperplastic capillaries and their possible involvement in the pathogenesis of fibrosis. Histopathology, 10: 543-551.

Blanshard, J. D., Veitch, D. (1989) Ossifying lipoma. Journal of Laryngology and Otology, 103: 429-431.

Buley, I. D., Gatter, K. C., Kelly, P. M. A., Heryet, A., Millard, P. R. (1988) Granular cell tumours revisited. An immunohistological and ultrastructural study. Histopathology, 12: 263-274.

Enzinger, F. M., Weiss, S. W. (1988) Soft Tissue Tumors, 2nd edn., C. V. Mosby Company, St. Louis, pp. 989.

Giddens, W. E., Jr., Tsai, C. C., Morton, W. R., Ochs, H. D., Knitter, G. H., Blakley, G. A. (1985) Retroperitoneal fibromatosis and acquired immunodeficiency syndrome in Macaques. American Journal of Pathology, 119: 253-263.
Hajdu, S. I. (1979) Pathology of Soft Tissue Tumors, Lea \& Febiger, Philadelphia, pp. 599.

Hultberg, B. M., Daugaard, S., Johansen, H. F., Mouridsen, H. T., Hou-Jensen, K. (1988) Malignant haemangiopericytomas and haemangioendotheliosarcomas: an immunohistochemical study. Histopathology, 12: 405-414.

McWilliam, L. J., Harris, M. (1985) Granular cell angiosarcoma of the skin: histology, electron microscopy and immunohistochemistry of newly recognized tumour. Histopathology, 9: 1205-1216.

Morales, A. R., Fine, G., Castro, A., Nadji, M. (1981) Cardiac myxoma (endocardioma). Human Pathology, 12: 896-899.

Pierard, G. E., Pierard-Franchimont, C., Van Cauwenberge, D., MeLotte, P., Christophe, J., Lapière, C. M. (1985) Histiocytofibrome et fibromatose palmaire de Dupuytren. Annales de Dermatologie et Venereologie, 112: 877-881.

Sarkisov, D. S., Pal'tsyn, A. A., Adamyan, A. A., Kolokol'chikova, E. G. (1984a) Electron-autoradiographic study of nucleic acid synthesis in normal adipose tissue and lipomas. Bulletin of Experimental Biology and Medicine, 97: 674-678.

Sarkisov, D. S., Pal'tsyn, A. A., Adamyan, A. A., Kolokol'chikova, E. G. (1984b) Blood vessel cells as the source of development of desmoid fibroma. Bulletin of Experimental Biology and Medicine, 96: 1778-1780.

Smolle, J., Auboeck, L., Gogg-Retzer, I., Soyer, H. P., Kerl, H. (1989) Multinucleate cell angiohistiocytoma: a clinicopathological, immunohistochemical and ultrastructural study. British Journal of Dermatology, 121: 113-121.

Sun, C. C. J., Toker, C., Breitenecker, R. (1982) An ultrastructural study of angiomatoid fibrous histiocytoma. Cancer, 49: 2103-2111.

Zelickson, A. S. (1966) A tubular structure in the endothelial cells and pericytes of human capillaries. Journal of Investigative Dermatology, 46: 167-171.

\section{Dear Sir,}

We were interested to read the 'Letter to the Editor' from Dr Beranek. In our clinical record of an 'Ossifying lipoma' we discussed principally the clinical aspects of the case since it presented an unusual cause of a lump in the neck.

We discussed briefly the aetiology of lipomas and ossification thereof; the more recent work detailed in the letter of Dr Beranek adds considerably to our understanding of this process as we were unable to do so in a case report.

Yours faithfully,

J. D. Blanshard

ENT Registrar

Royal United Hospital

D. Veitch

Combe Park

Bath BA1 3NG 